\title{
微細骨粉含浸多孔質アパタイトブロックの異所性骨形成に及ぼす 栄養貫通孔の効果
}

\author{
峯 野 誠 司 \\ 東京医科歯科大学大学院医歯学総合研究科 蕦顔面頸部機能再建学系専攻 \\ 顎顔面機構制御学講座 顎顔面解剖学分野 \\ (主任・指導：山下靖雄教授) \\ (指導：小木曾 誠博士）
}

(2007 年 2 月 1 日 受付)

\begin{abstract}
Effects of Nutrient Channels on Ectopic Bone Formation in Porous Apatite Blocks Impregnated with Super Fine Bone Powder
\end{abstract}

\author{
Mineno Seiji \\ Maxillofacial Anatomy, Department of Maxillofacial Biology, \\ Division of Maxillofacial/Neck Reconstruction, Graduate School, \\ Tokyo Medical and Dental University \\ (Chief and Director: Prof. Yamashita Yasuo) \\ (Director : Dr. OGIso Makoto)
}

\begin{abstract}
In this study, we prepared four types of 10-mm-diameter, 10-mm-long, large, columnar, bone powderimpregnated, porous apatite blocks, which did or did not have a single nutrient channel of 1,2 , or $3 \mathrm{~mm}$ in diameter in the long-axis direction. We implanted them in the subcutaneous tissue of adult dogs for 4 , 8 , or 16 weeks, and examined the status of bone formation in each block. As a result, bone formation started with the differentiation of osteoblasts along the wall of macro-pores within an area of dense multinucleated cells, and the area of bone formation consisting of bone along the pore wall and bone marrow in the pores gradually expanded around the block in a ring fashion and inward or outward. In apatite blocks with a 2or 3-mm nutrient channel, bone formation also proceeded along the channel in the block. At 16 weeks after implantation, even in the middle level, almost the entire porous apatite block with a 3-mm channel became the area of bone formation. However, in other apatite blocks, there remained an area without bone formation ; in particular, in blocks without a nutrient channel or with a 1-mm nutrient channel, there remained an area slightly over $4 \mathrm{~mm}$ in diameter without bone formation at the middle level. These findings indicate the importance of the nutrient channel for good bone formation in large blocks.
\end{abstract}

\section{I. 緒 言}

外傷, 腫瘍, 外科的侵襲などによる骨欠損部また抜歯, 義歯の長期装用などによる顎堤萎縮部の骨の回復治療に 際して，これまでは二次的侵襲を伴うものの自家骨移植 が最善の方法とされてきた ${ }^{1 \sim 3)}$ 。骨を用いない方法として は従来, 骨親和性が良好で骨伝導能を有するアパタイト やリン酸三カルシウム (TCP) などのセラミックスによ る人工骨が用いられてきた ${ }^{4 \sim 7}$ 。しかし，これらの人工骨 は移植床の骨との接合部で両者が結合するものの, 人工
骨のスペースが骨組織になるわけではない。骨欠損部へ の単なる補填材の応用には限界があり, 真の骨再生を得 るためには骨誘導能を生じさせる因子また素材の開発が 必要である。この観点からさまざまな増殖因子の研究が 行われ ${ }^{8 \sim 10)}$, また骨髄幹細胞を用いた組織工学的手法に よる再生医療の研究が精力的に進められている11 13)。最 近ではこれらの研究とは別に, 特殊な構造の多孔質アパ タイトには骨誘導能があることが報告されるようになっ た ${ }^{14 \sim 31)}$ 。

アパタイトは従来, 骨伝導能を有するものの, 骨誘導 
能はないとされてきた ${ }^{30 \sim 34)}$ 。しかし，連通する数百 $\mu \mathrm{m}$ のマクロ気孔をもつとともにその気孔壁にも $1 \mu \mathrm{m}$ 以下 〜数 $\mu \mathrm{m}$ のミクロ気孔を有する特殊な構造の多孔質ア パタイトは異所性においても骨組織形成能があり, 特に ミクロ気孔の分布が重要と考えられている。この多孔質 アパタイトの骨誘導能に関し, 著者らが行った $6 \mathrm{~mm}$ 立 方サイズで気孔率約 $85 \%$ の多孔質アパタイトを犬の皮 下脂肪組織に埋入した実験では, ブロック内の骨形成の 開始は移植後 6 週程度と比較的遅いとともに骨形成発現 部位が不規則で,また 12 週にいたっても骨形成はブロッ ク内方域の一部にとどまる ${ }^{26)}$ 。 Havibovic らの報告もこ れに準じている ${ }^{23)}$ 。の程度の骨形成能ではその臨床応 用が難しい。しかし，この多孔体にわずかな量の微細骨 粉を含浸させることでその骨誘導能が飛躍的に向上する ことが認められた ${ }^{26,30) 。}$

著者らが行ったこの微細骨粉含浸多孔質アパタイトを 用いた $6 \mathrm{~mm}$ 立方サイズ程度のブロックの異所性埋入 実験では, 埋入後早期にブロック内が新生骨組織で満た される。しかし, $10 \mathrm{~mm}$ 程度の肉厚ブロックになるとブ ロック辺縁部での骨形成は得られるものの内部の骨形成 が困難であることを認めた ${ }^{26)}$ 。一方, Havibovic らは多孔 質アパタイトの骨形成能は小さなブロックでは発揮され にくく，大きなブロックのほうが骨形成能が高いと相反 する報告をしている ${ }^{23)}$ 。また多孔質アパタイトおよび微 細骨粉含浸多孔質アパタイトの骨形成機序に関してもい まだ不明な点が多い。

そこで今回，ブロックが大型になると内部の骨形成が 難しくなることが認められている多孔質構造体の直径 $10 \mathrm{~mm}$, 高さ $10 \mathrm{~mm}$ の円柱状ブロックを用い, それにさ まざまな大きさの栄養貫通孔を設けた微細骨粉含浸多孔 質アパタイトブロックの皮下脂肪組織への埋入実験を行 い，それぞれのブロック内の骨形成機序の詳細を調べる とともに，大型ブロック内に良好な骨形成を得るために はどのような配慮が必要なのか, また Havibovic らの相 反する報告についての考察を行つた。

\section{II. 方法}

\section{1、多孔質アパタイト}

本実験に用いた多孔質アパタイトは $\mathrm{Ca}(\mathrm{OH})_{2}$ および $\mathrm{H}_{3} \mathrm{PO}_{4}$ を出発原料としており,アパタイト合成を行った 後, スプレードライで平均粒径 $15 \mu \mathrm{m}$ の粉体を作製, こ の球状粉体をスラリー状態で粉砕後, さらに水溶性高分 子および界面活性郕を添加した後, 気泡を導入して発泡 させゲル化乾燥を経てブロック体としたものである。こ れを所定形状に加工後 $1,200^{\circ} \mathrm{C}, 4$ 時間, 大気中で焼結を 行い作製されたものである(ペンタックスより提供)。こ の多孔質アパタイトは気孔率約 $82 \%$ で圧縮強度約 2.4

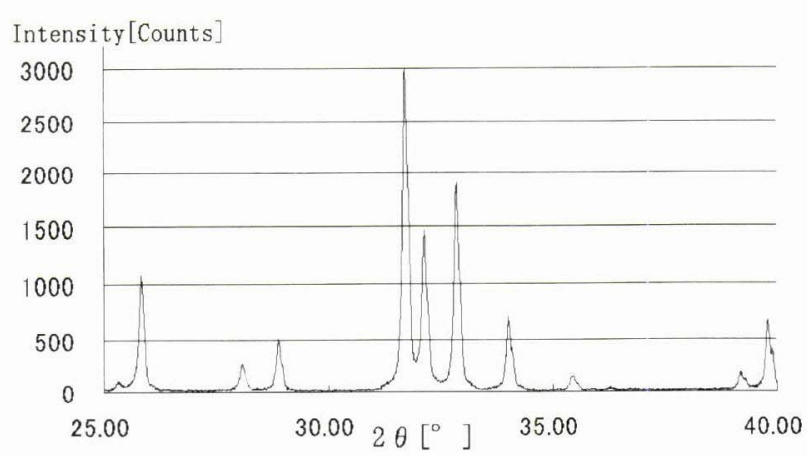

図 1 多孔質八イドロキシアパタイトの X 線回折パターン

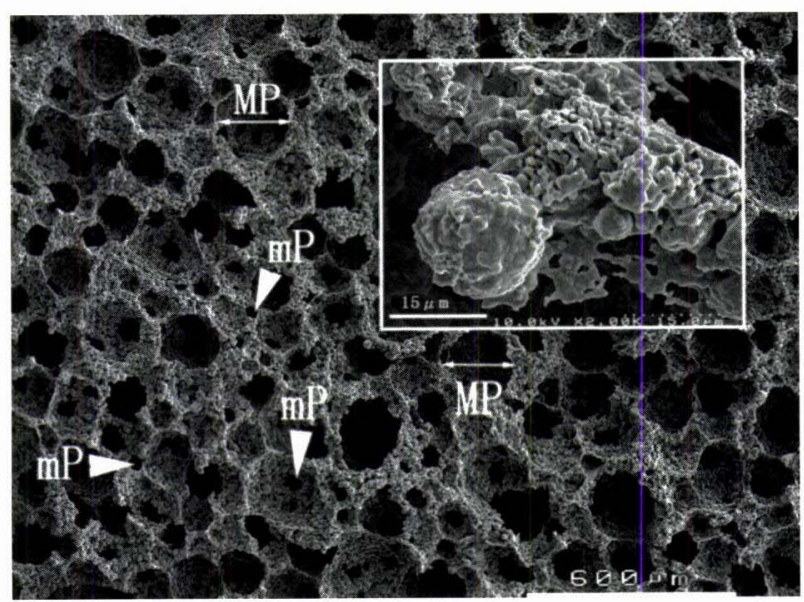

図 2 多孔質ハイドロキシアパタイトの SEM 像 マクロポア (MP) の気孔壁に沿ってミクロポア $(\mathrm{mP})$ が みられる。

$\mathrm{MPa}$ の高気孔率多孔体である。またこの多孔体は図 1 の X 線回折パターンに示されるようにほぼ純粋なハイド ロキシアパタイトであり，その構造は図２にみられるよ うに平均 $40 \mu \mathrm{m}$ 程度の連通孔を介した $150 \mu \mathrm{m}$ 前後の マクロ気孔を有するとともに, マクロ気孔壁を構成する 二次粒子の相互間に数 $\mu \mathrm{m} の ミ ク ロ$ 気孔をもち，かつ二 次粒子内にも $1 \mu \mathrm{m}$ 以下の空隙をもつ構造である。埋入 実験に用いた多孔体形状は直径 $10 \mathrm{~mm}$, 高さ $10 \mathrm{~mm}$ の 円柱状ブロックで，このブロックに栄養貫通孔を設けな いもの（貫通孔 $0 \mathrm{~mm}$ ) およびその中央に長軸方向の直径 1, 2, $3 \mathrm{~mm}$ の栄養貫通孔をそれぞれ 1 個設けたものの計 4 種類（貫通孔 $1 \mathrm{~mm}$, 貫通孔 $2 \mathrm{~mm}$, 貫通孔 $3 \mathrm{~mm}$ ) で ある。

\section{2. 微細骨粉}

本実験では多孔質アパタイトに微細骨粉を含浸させ た。骨粉は埋入を行う成犬の脛骨からの採骨片をすでに 報告している方法 ${ }^{26,30)}$ で粉砕したもので，その粒径は レーザー回折によると $4 \mu \mathrm{m}$ をピークにし, 透過電子顕 微鏡観察ではサブミクロンサイズのものが圧倒的に多い ことが認められている ${ }^{26)}$ この骨粉を $-80^{\circ} \mathrm{C}$ で保存し, 適 
宜解凍して用いた。多孔体への骨粉含浸に際して, 同犬 の血漿を用いて骨粉の濃度が緻密骨の骨濃度を基準に約 $1 / 100$ 濃度となるように調整した骨粉懸濁液を含浸させ た。そして埋入時に血漿を凝血させた。

\section{3. 埋入実験}

埋入用動物として生後約 12 カ月の実験用ハイブリッ ド犬 2 頭の兄弟犬を用い，背部皮下脂肪組織に 4 種ブ ロックをそれぞれ 3 個ずつ埋入した。埋入 4 週, 8 週, 16 週後に 4 種ブロックを各 1 個ずつブロック周囲組織をわ ずかに付着させた状態で摘出し組織標本とした。なお本 実験は, 東京医科歯科大学動物実験委員会の承認の下, 同施設で行い，手術に際しては全身麻酔下，無痛状態で 行った。

\section{4 、組織所見}

1) 組織学的観察

摘出ブロックを $10 \%$ ホルマリンにて固定後, 通法に 従って樹脂 (Rigolac, 応研商事) 包埋した標本をダイヤ モンドバンド鋸による薄切機（EXAKT，Apparatebau， Otto Hermmann, Germany）にて $800 \mu \mathrm{m}$ 間隔でブロッ クの未脱灰横断切片を作製し，トルイジンブルー染色(以 下, T. B. 染色)を行った後, ブロック内の組織形成につ いて光学顕微鏡を用いて観察した。

\section{2) 形態計測}

ブロック内の骨形成範囲を計測するため，すべての切 片に扔ける多孔質アパタイト部分に占める骨形成域比率 を顕微鏡写真を用い, イメージングソフトウェア (photoshop, adobe, USA）にて測定した。

\section{III，結 果}

\section{1. 組織学的観察}

1) 埋入 4 週後の標本

ブロック内の表面寄りの部位では毛細血管，ならびに 微細な線維を主体とした結合組織が出現している領域 (以後，この領域を便宜的に組織形成域とする)がみられ る。この組織形成域の範囲は, ブロックの種類よりブロッ クの部位によって異なる（図 3)。ブロック周囲に密な線 維組織からなるカプセリングがほとんど形成されていな い部，またその厚みが非常に薄い部では組織形成域がブ ロック表面から中心側へ $2 \mathrm{~mm}$ 程度まで拡大している が，カプセリングの厚みが $100 \mu \mathrm{m}$ 程度では組織形成域 は $1.5 \mathrm{~mm}$ 程度である。またカプセリングの厚みが 200 $\mu \mathrm{m}$ 以上の部では組織形成域がさらに狭く,一部 $400 \mu \mathrm{m}$ 程度の部では組織がほとんど形成されていない。200 $\mu \mathrm{m}$ 以上の厚いカプセリングが生じている部はブロック横断 切片の各レベルにおける 1 力所もしくは 2 力所で, 埋入 されたブロックが筋肉側に位置した領域の端部に相当す るものが多く，比較的広い範囲にわたり長軸方向に連続
している。カプセリングの厚みが $100 \mu \mathrm{m}$ 程度以下の部 では組織形成域内で骨形成が始まっている。また貫通孔 をもつブロックでは，貫通孔にも組織形成が進行し，特 に貫通孔 $2 \mathrm{~mm} ， 3 \mathrm{~mm}$ ではブロック中央レベルにおい ても線維の形成が始まっている。これらのブロックでは 貫通孔側からブロック内への組織形成も始まっている が，その幅はブロック上下端部から中央レベルに移行す るにつれ減少し，中央レベルではいまだみられない。貫 通孔 $1 \mathrm{~mm}$ のものでは貫通孔内の組織形成が遅れ, 端部 から 2〜3 $\mathrm{mm}$ 入ると毛細血管はみられなくなる。

組織形成域の最深部では，マクロ気孔内に毛細血管の ほか単核性の細胞が疎な状態で分布しているにすぎない が，その外側寄りでは骨粉の凝集塊に破骨細胞が出現し アパタイトのマクロ気孔壁に沿っても多核細胞がみられ る。外側に移行するにつれ気孔内に破骨細胞, 多核細胞 の出現が多くなり，やがて気孔壁に沿って大きさ $50 \mu \mathrm{m}$ 以下の多核細胞が密に配列した状態となる。多核細胞が 密に出現している領域の一部で気孔壁に沿って骨芽細胞 が出現し，骨前質様組織形成に引き続いて石灰化による 骨形成が始まっている（図 4)。骨形成の開始部位では骨 粉凝集塊がほとんど消失しているが，一部では気孔内に 骨粉凝集塊が残存しており，その凝集塊に沿っても周囲 気孔壁での骨形成とほぼ同時に骨形成が生じている。多 核細胞出現域に囲まれた骨形成域の先端部では，マクロ 気孔においても大きな気孔の壁表面に先立って, 上り小 さな気孔内で骨形成の始まる状態が各所で認められる。

ブロック辺縁での骨形成は，いずれのブロックも，一 部非連続の円弧状に同心円の $1 / 2 \sim 2 / 3$ の範囲で形成さ れている(図 3)。また骨形成域の幅は組織形成域の幅に 相関し, 最も広い部で $1 \mathrm{~mm}$ 程度となっている。しかし, カプセリングが薄くブロック内方への組織形成域が広い 部においても，ブロック表面がわずかに崩れ，崩れた気 孔壁砕片に比較的大きな多核細胞が出現している領域て はブロック内部に骨形成がみられない。相当域のブロッ ク表面寄りでは気孔壁に沿って多核細胞が出現せず骨粉 も各所に残存している。

骨形成域内部では気孔壁に沿って骨が添加形成され， その結果骨は網目状に形成された状態となっている。骨 形成域では添加骨の肥厚とともに破骨細胞による骨吸収 がみられ，また気孔壁の各所に多核細胞が出現している。 多核細胞には，アパタイトの一次粒子の取り込みがわず かにみられ，その結果マクロ気孔の連通孔が分化の生じ ていない部に比べ骨形成域内で拡大している。拡大され たマクロ気孔内には骨髄の形成とともに，洞様毛細血管 がみられる。

ブロック内でブロック内側から外側へと拡大している 骨形成先端部，またすでに骨形成が生じている部で気孔 
壁に沿った骨が最も肥厚している部のブロック表面から の深さは, ブロック周囲のカプセリングの厚さで異なる。 カプセリングが非常に薄い部ではおおむね $0.7 \sim 0.8$ $\mathrm{mm}$ であるのに対し, $100 \mu \mathrm{m}$ 程度のカプセリングの部 では $0.5 \mathrm{~mm}$ 以下となっている。また骨形成域とブロッ ク表面の間には，骨形成がすでに生じている部において も骨未形成域が介在し，その幅も外側のカプセリングの 厚さで異なる。カプセリングの非常に薄い部は骨未形成 域を $0.5 \mathrm{~mm}$ 程度残し, その骨形成側は気孔壁に多核細 胞がみられるが，ブロック表面側にはこれら細胞が少な く気孔内に骨粉の残存が多い。一方, $100 \mu \mathrm{m}$ 程度のカプ セリングの部では骨未形成域幅が狭いとともに，その幅 のほほ全域で多核細胞が出現している。また貫通孔を有 するブロックではその端部からやや入ったレベルで貫通 孔周囲のブロック内に骨形成が生じており，この部の骨 形成は貫通孔壁から形成され，貫通孔壁と骨形成域の間 には骨末形成域が認められない（図 5)。骨形成が生じて いない部分では，多核細胞が貫通孔壁からブロック内方 に向かって連続して認められる。

\section{2 ) 埋入 8 週後の標本}

ブロック内組織形成域は貫通孔 $2 \mathrm{~mm}, 3 \mathrm{~mm}$ のブ ロックでは 4 週からかなり拡大している(図 6,7)。中央 レベルにおいても, 貫通孔 $2 \mathrm{~mm}$ のものはブロック外側 から内方へ 2〜2.5 mm に拡大し, 貫通孔側からの組織 形成域も 0.5 1 mm となり両者組織形成域間に残存し ている組織未形成域幅は $1 \mathrm{~mm}$ 程度になっている。また 貫通孔 $3 \mathrm{~mm}$ のブロックでは組織未形成域が消失して いる。しかし, 貫通孔 $0 \mathrm{~mm}, 1 \mathrm{~mm}$ のブロックの組織形 成域は端部側から中央レベルに移行するにつれ，ブロッ ク外側寄りに狭くなり, 中央レベルでの組織形成域は外 側の $2 \mathrm{~mm}$ 程度の幅にすぎない部が多く，カプセリング が薄い部のほうが厚い部に比べ組織形成域は広い（図 8, 9)。一部で $200 \mu \mathrm{m}$ を超えるカプセリングが生じている 部がみられ，相当域での組織形成域幅は $1 \mathrm{~mm}$ 程度であ る。また貫通孔内も中央レベルでは貫通孔内に組織形成 が始まった段階にすぎない。

骨形成域は 4 週から拡大し，いずれのブロックも周囲 の全域にリング状に広がっている。ブロック中央レベル における骨形成域幅は貫通孔 $0 \mathrm{~mm}, 1 \mathrm{~mm}$ のものでは $0.5 \sim 1.5 \mathrm{~mm}$ で, 貫通孔 $2 \mathrm{~mm}$ のものは $1.5 \mathrm{~mm}$ 程度の 部が多く, 貫通孔 $3 \mathrm{~mm}$ では $2 \mathrm{~mm}$ 程度である。また貫 通孔 $2 \mathrm{~mm}, 3 \mathrm{~mm}$ のものでは貫通孔寄りにも骨が形成 されており，特に貫通孔 $3 \mathrm{~mm}$ のブロックでは貫通孔の 半周程度の領域で約 $1 \mathrm{~mm}$ の幅で骨が形成されている。

骨形成域の内部では気孔壁に沿って形成された骨が 4 週の状態よりも肥厚し, 染色性が低下し石灰化が方進し た骨となっている。これらの骨や気孔壁には破骨細胞や
多核細胞が各所に出現しており，その結果髄腔または骨 の網目が拡大している。吸収部の一部では気孔壁と骨表 面にまたがって一個の多核の細胞が付着している状態が 認められる。拡大した髄腔は主として外側から内側へま た長軸方向に連通し，髄腔内には洞様毛細血管がその大 半を占めた状態となっている。骨形成域の外側ではフォ ルクマン管様のやや広い血管腔を残し，骨が骨形成域の 外側面を連続するように形成されている部が多い。これ らは特にブロック周囲のカプセリングが $100 \mu \mathrm{m}$ 程度 で，骨形成域がブロック表面に近接している領域で顕著 にみられる。

ブロック内部の組織未形成域に分布する骨粉は 4 週に 比べ異調染色が顕著になっており, 特に組織形成域に隣 接する部では個々の微細な骨粉が石灰沈着の亢進により 肥厚し，隣接の骨粉と癒合することで骨粉凝集域が一塊 の大きな石灰化物の様相を呈しているものが多くなって いる。またそのような領域の気孔壁もそれを構成する二 次粒子表面が異調染色されている。ブロック外側寄りに みられる骨形成域とブロック内側の組織未形成域の間の 組織形成域の幅は，貫通孔 $3 \mathrm{~mm}$ のブロックを除き 0.5 $\mathrm{mm}$ 程度の部分が多く（図 6 9）これらの領域も石灰化 の六進した骨粉凝集塊が散在している。すなわち，この 時期の骨形成域の内側先端部では 2 通りの骨形成パ夕ー ンがみられる。

多くの領域では，マクロ気孔内にやや拡張した毛細血 管がみられるとともに気孔壁や骨粉凝集塊の各所で多核 細胞が出現している。そのような領域内で骨形成端から 連続する骨芽細胞に被覆された骨前質がそれら表面に添 加形成され，骨形成が進行している。

しかし一部では，骨粉凝集塊や気孔壁に多核細胞が特 に出現することなく，それらの周囲に密な線維が比較的 幅広く形成され，また一部の気孔ではこの線維組織で満 たされ, 気孔壁や骨粉凝集塊からその線維組織に石灰化 域が拡大している(図 10)。線維組織の密度, 幅は一定で はないが，毛細血管がみられず，骨芽細胞様細胞がみら れることから骨前質様組織の特徴を示している。また気 孔壁や骨粉周囲に骨前質様組織や密な線維が特に形成さ れていないにもかかわらず，石灰化の六進した気孔壁や 骨粉塊からその周囲の疎な線維に沿って石灰化域が拡大 する状態もみられる。後者の石灰化域は周囲の組織分化 がそれほど進行せず線維密度も低い部で生じている（図 11)。しかしそのわずかに骨形成域寄りではその周囲に厚 い骨前質様組織が形成され，石灰化域が拡大している。 このようにして気孔内は石灰化が方進した骨様組織で満 たされている。またこの骨様組織内の各所には石灰化の 六進した骨粉塊が封入されており，不規則な小腔や樹状 の未石灰化域が残存している。ブロック外側域ではみら 


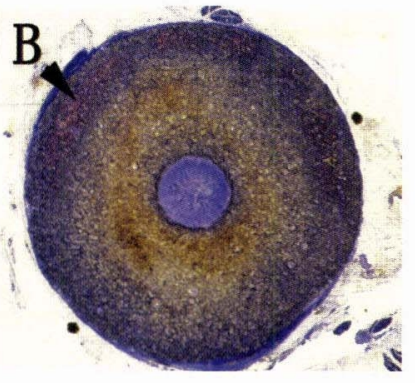

図 3 埋入後 4 週のブ ロック中央レベルに おける横断切片

ブロックの辺縁部で組 織形成がみられ, 辺縁の $1 / 2$ 程度の範囲で骨形成 (B) が進行している（T B. 染色)。

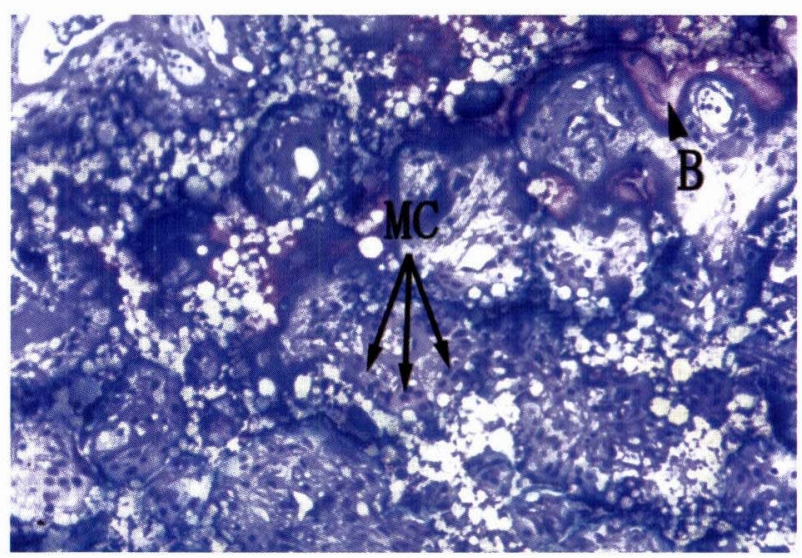

図 4 埋入後 4 週

アパタイト気孔壁に沿って多核細胞 (MC) が出現している 領域の一部で，アパタイト気孔壁に沿った骨形成（B）が始 まっている (×25，T. B. 染色)。

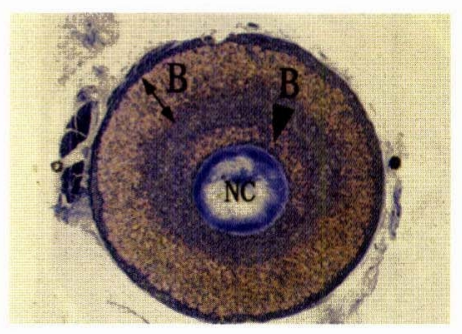

図 6 埋入後 8 週の貫通 孔 $3 \mathrm{~mm}$ ブロックの 中央レベルにおける 横断切片

ブロック内に異調染色 された $2 \mathrm{~mm}$ 程度のリン グ状の骨形成 (B) がみら れるとともに，貫通孔 (NC) 側にも骨形成 (B) がみられる。組織形成域 は青く濃染されている (T. B. 染色)。

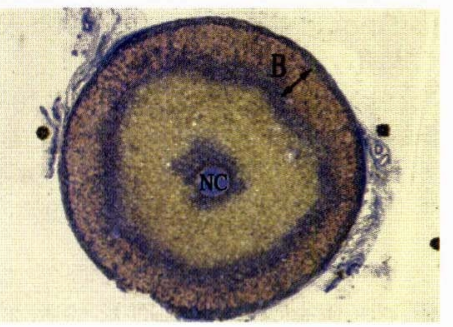

図 8 埋入後 8 週の貫通 孔 $1 \mathrm{~mm}$ ブロックの 中央レベルにおける 横断切片

組織形成域はブロック 外側より $2 \mathrm{~mm}$ 程度で,

- 1 1.5 mm 幅で骨形成 (B) がみられる。ブロッ ク中央部の染色されてい ない部は組織未形成域で ある (T. B. 染色)。
れないこのようなプロセスで形成された骨組織も，骨形 成域の内側寄りでは骨吸収による髄腔形成また骨前質形 成などのリモデリングが生じている。

骨形成域内側でみられる髄腔がみられない状態で形成 される骨形成は，貫通孔周囲の骨には広範にみられる。 髄腔のない骨形成域の幅はリモデリングが遅れているこ ととも関連し，外側の骨形成域に比べ広い。

骨形成域外側とブロック表面の間に残存する骨未形成

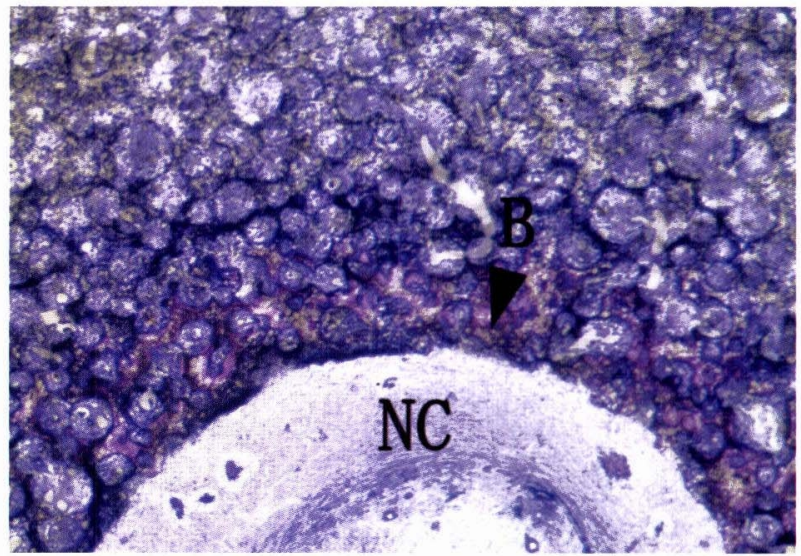

図 5 埋入後 4 週

貫通孔（NC）側に形成されている骨（B）は，貫通孔壁と 骨形成域の間に，骨末形成域を残していない(T. B. 染色)。

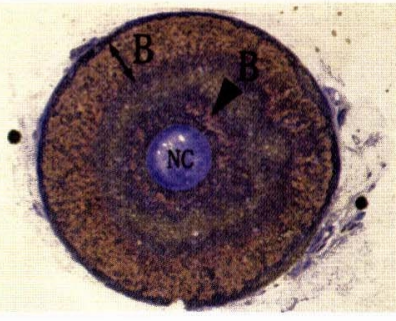

図 7 埋入後 8 週の貫通 孔 $2 \mathrm{~mm}$ ブロックの 中央レベルにおける 横断切片

ブロック内に $1.5 \mathrm{~mm}$ 程度のリング状の骨形成 (B) がみられ, 貫通孔 (NC) 側にも骨形成 (B) がみられる (T. B. 染 色)。

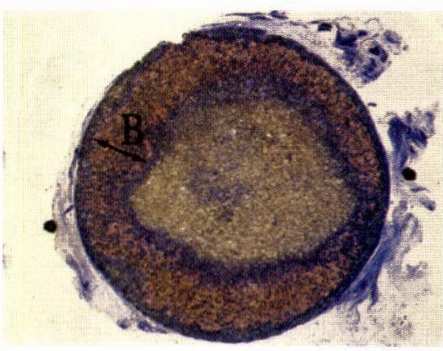

図 9 埋入後 8 週の貫通 孔 $0 \mathrm{~mm}$ ブロックの 中央レベルにおける 横断切片

組織形成域はブロック 外側より $2 \mathrm{~mm}$ 程度で, $0.5 \sim 1.5 \mathrm{~mm}$ 幅で骨形 成（B）がみられる。ブ ロック中央部の染色され ていない部は組織未形成 域である(T.B. 染色)。 


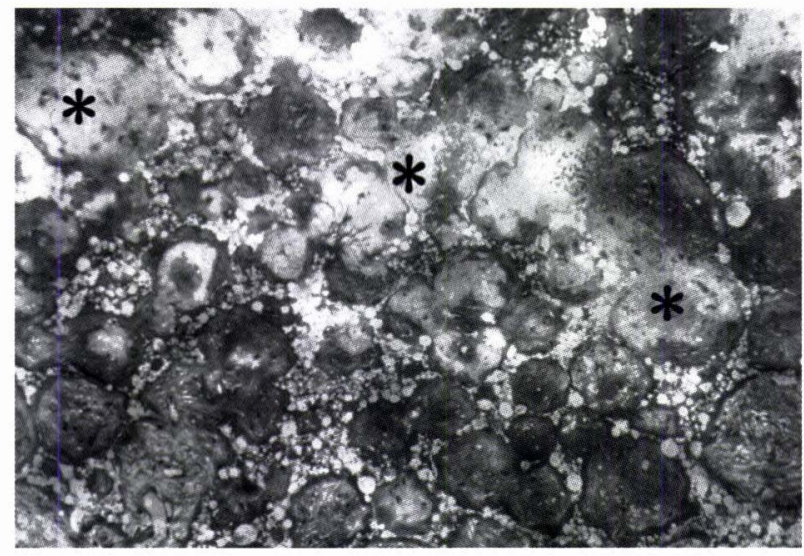

図 10 埋入後 8 週のブロック内部骨形成域の一部の拡大 骨粉凝集塊や気孔壁周囲に密な線維が形成され，その線維 形成域の石灰化により髄腔にみられない骨形成（＊）が気孔 内で生じている $(\times 33$, T. B. 染色 $) 。$

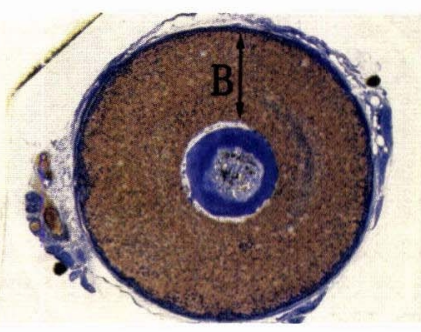

図 12 埋入後 16 週の貫 通孔 $3 \mathrm{~mm}$ ブロッ クの中央レベルに おける横断切片

ブロックのほぼ全域に 骨形成（B）がみられる (T. B. 染色)。
域の幅も 4 週よりわずかに狭くなり，力プセリングが $100 \mu \mathrm{m}$ 程度の部は $0.2 \mathrm{~mm}$ 程度となり, カプセリング が薄いもしくはほとんどみられない部も全体として 4 週 より狭くなっているが, $0.5 \mathrm{~mm}$ 以上の広い部も残存し ている。このような骨未形成域は長軸方向に連続してお り，ブロック表面はわずかに崩壊し多核細胞が出現して いる。この多核細胞は骨形成域周囲にみられる多核細胞 に比べ大きく大小さまざまなアパタイト粒子の取り込み が顕著である。いずれの部も骨末形成域と接する骨形成 域外側面では骨や周囲気孔壁に骨前質が追加形成されて いる部が多い。

3 ) 埋入 16 週後の標本

すべてのブロックで全域が組織形成域になり，骨形成 域も 8 週から拡大している。特に貫通孔 $3 \mathrm{~mm}$ のブロッ クでは一部を除きほぼ全域が骨形成域になっている（図 12)。他のブロックではブロック上下端部から 2～3 mm 中央レベルに移行すると，貫通孔 $0 \mathrm{~mm}$ のブロックでは

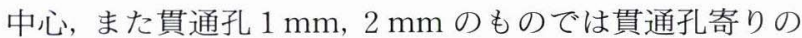
骨と外側寄りの骨の間に骨未形成域がみられ，それら骨 未形成域は中央レベルで最も広くなる。貫通孔 $2 \mathrm{~mm} の$ ブロックの骨形成域は貫通孔 $0 \mathrm{~mm}, 1 \mathrm{~mm}$ に比べやや 広く, 中央レベルでブロック表面側から内方に 3 $4 \mathrm{~mm}$

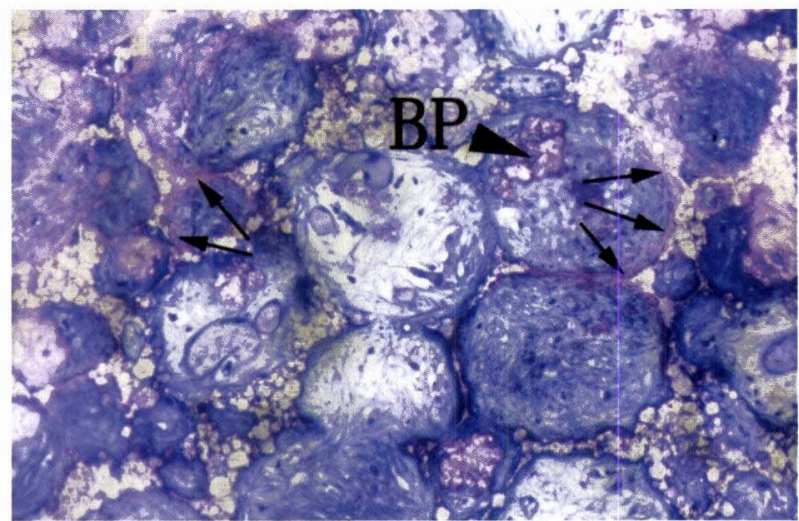

図 11 埋入後 8 週のブロック内部骨形成域の一部の拡大

気孔内に形成されている疎な線維に沿って，石灰沈着の元 進した骨粉凝集塊（BP）やアパタイト気孔壁から石灰化域 $(\rightarrow)$ が広がっている（×66，T. B. 染色）。

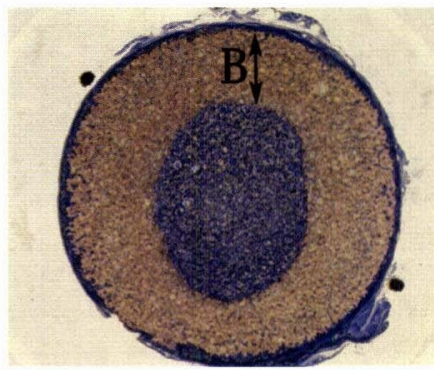

図 13 埋入後 16 週の貫 通孔 $0 \mathrm{~mm}$ ブロッ クの中央レベルに おける横断切片

ブロックの中央部に $4 \sim 5.5 \mathrm{~mm}$ の範囲で楕 円状に骨未形成域がみら れる (T. B. 染色)。

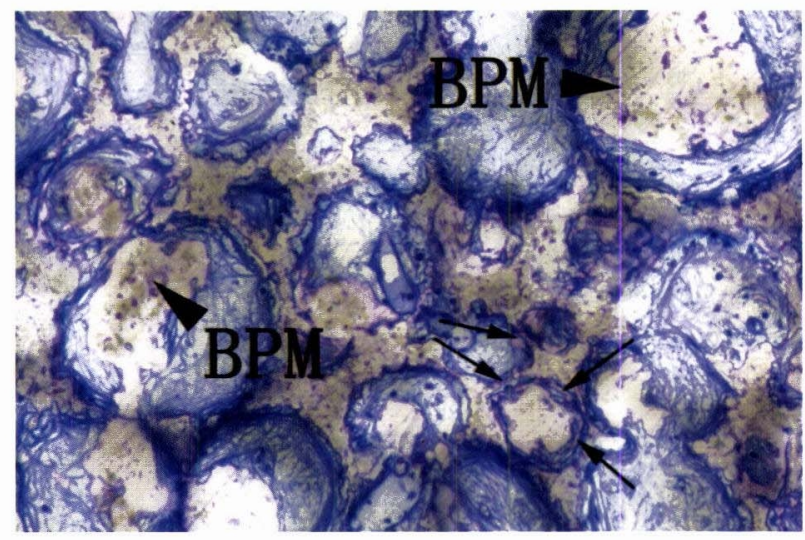

図 14 埋入後 16 週の貫通孔 $0 \mathrm{~mm}$ ブロックの中央域の骨未 形成域の拡大

骨未形成域のマクロ気孔内には石灰沈着の元進により 100 $\mu \mathrm{m}$ 程度に肥厚した緻密な骨粉凝集塊 (BMP) が散在してお り，一部ではそれら骨粉またアパタイト気孔壁から周囲の疎 な線維に石灰沈着 $(\rightarrow)$ が生じている $(\times 66$, T. B. 染色)。

の部分が多く，一方の個体では貫通孔側にも骨形成がみ られる。貫通孔 $0 \mathrm{~mm}$ (図 13), 貫通孔 $1 \mathrm{~mm}$ のブロック では基本的には差がない。ブロック内側への骨形成域の 拡大は必ずしも同心円状ではない。特に貫通孔 $2 \mathrm{~mm}$ の 一方の個体のブロックでは部分的にブロック表面から 1 
$\mathrm{mm}$ 程度とかなり浅く, 相当域はブロックが筋肉側に埋 入された位置の端部でブロック外側に $200 \mu \mathrm{m}$ 程度の厚 いカプセリングが形成されている。貫通孔 $3 \mathrm{~mm}$ のブ ロックにも中央レベルよりややブロック上下端部寄りで 貫通孔周囲の一部に骨未形成域が残存し，これらの相当 部もブロックが同様の部に位置し，厚いカプセリングが 認められる。

骨形成域はブロック表面側へも若干拡大しており，ブ ロック表面側のカプセリングが $100 \mu \mathrm{m}$ 以上の厚さの部 では骨未形成域幅が $0.1 \mathrm{~mm}$ 未満となり骨形成域はほ とんどブロック表面に達している。またカプセリングが 薄い部も骨未形成域幅が $0.1 \sim 0.3 \mathrm{~mm}$ となっている領域 が多い。しかし,カプセリングの薄いブロック表面側の一 部では比較的幅の広い骨未形成域が残存している。特に 貫通孔 $2 \mathrm{~mm}$ のブロックの一個体のものではその一部 で $0.7 \mathrm{~mm}$ 程度の幅の骨未形成域が残存している。相当 域のブロック表面にはブロックの崩壊が認められる。

ブロック内側に残存する骨未形成域には血管系の分布 が少ない線維組織が形成され，そのなかでも骨形成域寄 りでは気孔内の線維が密になっている。密な線維が形成 されている領域では骨粉は減少しているが，内側寄りの 線維が踈な領域では骨粉が肥大化し緻密化した石灰化物 が各所にみられる。骨粉塊は $100 \mu \mathrm{m}$ 以下の大きさのも のが多いがそれ以上の大きさになっているものも認めら れ，貫通孔 $0 \mathrm{~mm}$ のブロックの中心部においても一部の 気孔は肥大化した骨粉塊でほほ占有されている。この領 域の一部では石圧沈着の進行した気孔壁や骨粉塊から周 囲の疎な線維に沿って，石灰沈着域がわずかに拡大して いる状態も認められる(図 14)。このような領域は骨形成 域とは完全に離れ, 周囲気孔壁の構造も埋入後 4 週の内 部の状態と基本的に変わらない。

骨未形成域に隣接する骨形成域内面では活発な骨形成 は認められなくなり，骨形成の生じていない部も多い。 骨未形成域に隣接する骨形成域のほほ全周で，リモデリ ングが進行している部が $1 \mathrm{~mm}$ 末満の幅でみられ，拡大 した髄腔には赤血球・白血球・巨核球などがみられる。 この部の骨には不規則な形態の小腔や樹状の未石灰化域 の残存する部が各所に認められる。しかし，ブロック端 部側の骨形成域から中央レベル側の骨未形成域内に伸張 してきている骨形成域では，気孔内に髄腔をもたない骨 組織がいまだ多い。骨形成域の内側から外側に向かうに つれ，髄腔に造血細胞がみられなくなるとともに，一部 の比較的広い髄腔を除き髄腔が狭くなり，その結果骨密 度が内側に比べ高くなっている。特に骨形成域の外側寄 りでは緻密骨の様相を呈している。

貫通孔内は上下方向に配列するとともに各所でブロッ ク内に向かって分枝する血管系抢よび線維が形成されて

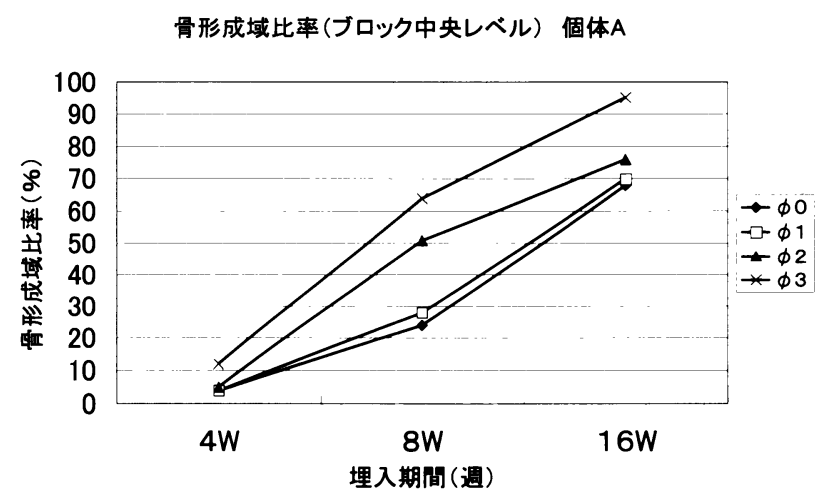

骨形成域比率(ブロック中央レベル）個体B

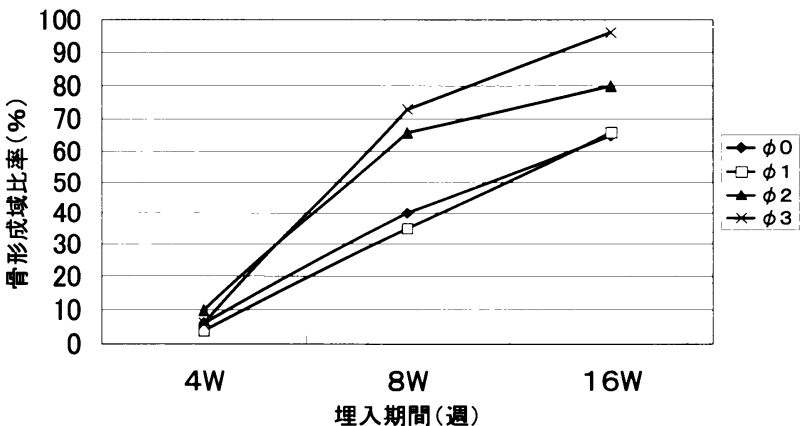

図 154 種ブロック中央レベルにおけるアパタイトに対する 骨形成域比率の経時的な推移

おり，気孔壁に沿っては密な線維が形成されている。し かし，貫通孔内面にも骨が形成されている部では貫通孔 寄りに骨䯣様組織が形成されている。

\section{2. 組織形態計測}

4 種ブロック内の骨形成範囲をすべての切片で多孔質 アパタイト部分に占める骨形成域の比率を計測している が，それぞれの埋入期間においてブロック端部に近い部 では 4 種ブロック間に特に差はみられない。しかし端部 側から中央レベルに移行するにつれ, 4 種ブロック間に 4 週のものを除き差がみられる。図 15 は，実験に用いた二 個体それぞれにおける 4 種ブロックの中央レベルにおけ る骨形成域比率の経時的な推移を示したものである。埋 入後 4 週の骨形成域比率はそれぞれのブロックに基本的 な差はみられない。埋入後 8 週では骨形成域比率がいず れのブロックも 4 週に比べかなり高くなるものの，貫通 孔 $0 \mathrm{~mm}, 1 \mathrm{~mm}$ と貫通孔 $2 \mathrm{~mm}, 3 \mathrm{~mm}$ の差は明確にな る。貫通孔広域を多孔質アパタイト部分としても貫通孔 $2 \mathrm{~mm}, 3 \mathrm{~mm}$ のブロックは貫通孔 $0 \mathrm{~mm}, 1 \mathrm{~mm}$ のものに 比べ明らかに高い。16 週になるとブロック間の差は 8 週 より差が縮小するものの, 一個体の貫通孔 $2 \mathrm{~mm}$ のブ ロックを除き, 貫通孔 $2 \mathrm{~mm}, 3 \mathrm{~mm}$ のブロックは貫通孔 $0 \mathrm{~mm}, 1 \mathrm{~mm}$ に比べ依然として高く, 特に貫通孔 $3 \mathrm{~mm}$ のブロックは二個体の平均が $95 \%$ と多孔質アパタイト 
部分のほとんどが骨形成域となっている。一個体の貫通 孔 $2 \mathrm{~mm}$ のブロックの比率が貫通孔 $0 \mathrm{~mm}, 1 \mathrm{~mm}$ のも のに近いのは, ブロック内での局部的な骨形成不良域に よる。

\section{IV. 考 察}

骨再生治療においては骨誘導能を生じさせる因子また 素材の開発が必要である。現在, 骨誘導因子となりうる 細胞増殖因子の局所への適用, さらに骨髄の間葉系幹細 胞を培養増殖して骨芽細胞に分化させた後, 局所に移植 する方法などが検討されている。增殖因子の代表例とし ての Bone Morphogenetic Protein (BMP) は, 1965 年 の Urist の報告 ${ }^{35)}$ に始まるが, 現在も動物の種によりそ の効果の差が指摘され，またヒトにおける効果も疑問視 されている ${ }^{36)}$ 。 BMP 以外の増殖因子の研究や ${ }^{37)}$, BMP を含浸させた徐放性材料の開発も行われているが38), 臨 床的有効性は明らかにされていない。

骨髄幹細胞から組織工学的手法を用い骨芽細胞を作製 する方法 ${ }^{39,40)}$ も現段階では形成可能な骨の量が少なく, 臨床応用は限定的な範囲で始まった段階である。ステロ イドホルモンや各種の因子が加えられた培養下で増殖・ 分化した骨芽細胞が生体内のものと同一か否かに疑問が あり, また生体幹細胞が既存の組織中の細胞と融合して 遺伝的に混同された細胞ができるリスクのあることも報 告されている ${ }^{41,42)}$ 。この方法が確立されたとしても, 一次 培養, 二次培養など長期に及ぶ維持管理に伴う経費は相 当なものと考えられる。

このような現状において，特別な增殖因子また細胞を 使用しなくとも単に人工の多孔質アパタイトを埋入する のみで骨が再生される可能性が指摘され，また臨床応用 上, 特に不可能ではない程度の採骨からの微細骨粉を含 浸させるのみでその骨誘導能を飛躍的に向上させうると いう事実は, 今後の骨再生医療に大きな期待をもたらし ている。しかし，その骨形成機序がいまだ不明確である。 そこで今回, 多孔質アパタイトの大型ブロックに栄養貫 通孔の付与という条件を設定し, ブロック内の骨形成機 序について検討を行った。

\section{1.ブロック内の組織形成について}

ブロック内の組織形成はブロックの外側面から，また 栄養貫通孔を有するものでは貫通孔側からも含めて毛細 血管がブロック内に侵入することでその端を発する。し かし, 毛細血管は $150 \mu \mathrm{m}$ 程度のマクロ気孔のみならず マクロ気孔相互間を連絡するわずか $40 \mu \mathrm{m}$ 程度の連通 孔を次々に通過しなければならず, 埋入 8 週後の時点で ブロックの全域に組織形成がみられたのは貫通孔 $3 \mathrm{~mm}$ のブロックのみである。またブロック外側面からの組織 侵入はブロック周囲に形成されている密な線維からなる
カプセリングの厚さに影響され，その影響は 8 週にい たっても認められ，また 16 週で組織形成域がすべてのブ ロックの全域に及んでもその範囲内で生じる骨形成に影 響を及ほしている。

ブロック内で最も早期に組織形成域が拡大する部はカ プセリングが非常に薄いもしくはほとんど形成されてい ない部に相当し, 埋入後 4 週でブロック表面から $2 \mathrm{~mm}$ 程度に達するのに対し, $100 \mu \mathrm{m}$ 程度の部では組織形成 域は $1.5 \mathrm{~mm}$ 程度で, $200 \mu \mathrm{m}$ 程度ではさらに狭く, 400 $\mu \mathrm{m}$ 程度の部ではブロック内部の組織形成はほとんどみ られない。このようなブロック外側からの組織侵入は 4 週以降は緩慢で, 8 週時点で上下方向からの影響も少な い貫通孔 $0 \mathrm{~mm}$ のブロック中央レベルでの組織形成域 は最大 $2 \mathrm{~mm}$ 程度にすぎず, 一部 $200 \mu \mathrm{m}$ 程度のカプセ リングの部ではわずか $1 \mathrm{~mm}$ である。それに対し貫通孔 $2 \mathrm{~mm}, 3 \mathrm{~mm}$ のブロックの貫通孔では 4 週でその中央レ ベルにまで線維形成を伴う毛細血管の侵入形成がみら れ, その後貫通孔側からの組織侵入が進み, 特に貫通孔 $3 \mathrm{~mm}$ のブロックでは外側からの組織侵入と貫通孔側か らの組織侵入が 8 週時点でブロック全域において一体化 している。これらのことはブロック内の早期の組織侵入 のためには貫通孔が欠かせないことを示している。しか し, 貫通孔 $1 \mathrm{~mm}$ のものでは貫通孔内での毛細血管の侵 入形成が遅く, 8 週にいたっても中央レベルでは貫通孔 内に組織形成が始まった段階で貫通孔からブロック内へ の組織侵入は生じていない。また今回の脂肪組織への埋 入では, ブロックが筋肉側に位置している部の端部相当 域の一部で $200 \mu \mathrm{m}$ またそれ以上のカプセリングが形成 されていたものの, 全体としては臨床応用が想定される 場とは異なり，ブロック周囲に形成されるカプセリング は薄いと考えられる。

以上よりブロックが今回の実験に用いた構造を有し, また大きさが今回のように大型の場合, 貫通孔が必要で あり, その貫通孔が 1 本であるとすれば直径 $2 \mathrm{~mm}$ 以上 のものが望ましい。

\section{2. ブロック内の骨形成域について}

ブロック内の骨形成は埋入後 4 週ではブロック周辺部 の全周に対し 1/2〜2/3 の範囲で非連続的に形成され, そ の骨形成域幅は厚い部でも $1 \mathrm{~mm}$ 程度である。ブロック 中央レベルで多孔質アパタイト部分に占める骨形成域比 率はわずかで各ブロック間に差はない。8週になるとす べてのブロックでブロック周囲の全域に骨形成域が広 がり,ブロック内方への骨形成域の拡大も進行する。しか し，この骨形成域の幅は基本的に組織形成域の幅に連動 し, 各ブロック間で大きな差が生じている。ブロック端部 の切片ではすべてのブロックで高い骨形成域比率を示す が, 中央レベルでは貫通孔 $0 \mathrm{~mm}, 1 \mathrm{~mm}$ ブロックと貫通 
孔 $2 \mathrm{~mm}, 3 \mathrm{~mm}$ ブロック間に大きな差が生じ, 特に貫通 孔 $3 \mathrm{~mm}$ で高い。16 週にいたると各ブロックの骨形成域 比率がさらに高くなりブロック間の差は縮小するもの の, 貫通孔 $2 \mathrm{~mm}, 3 \mathrm{~mm}$ のブロックは貫通孔 $0 \mathrm{~mm}, 1$ $\mathrm{mm}$ に比べ依然として高く, 特に貫通孔 $3 \mathrm{~mm}$ のブロッ クは二個体の平均が約 $95 \%$ と多孔質アパタイト部分の ほとんどが骨形成域となっている。

ブロック内の骨形成は 4 週では骨形成域周囲の気孔壁 に沿って骨前質の形成されている範囲が広く，骨形成域 の拡大が早い状態を示しているのに対し，16 週にいたる と骨形成がほとんど静止した状態になっており，骨未形 成域には血管系の少ない線維組織が形成されている。し たがって，貫通孔 $0 \mathrm{~mm}, 1 \mathrm{~mm}, 2 \mathrm{~mm}$ のブロックに 16 週時点で残存する骨未形成域が骨形成域になるためには 16 週以降かなりの期間を有するものと考えられる。

以上より，ブロック内での良好な骨形成を期すために は早期にブロック内に組織形成域が拡大することが好ま しく，大型ブロックでは栄養貫通孔の設置が必要で，今 回の条件のブロックでは直径 $3 \mathrm{~mm}$ の貫通孔が最良で あった。

\section{3. 骨形成機序について}

多孔質アパタイトの骨誘導能の機序についてはさまざ まに推測されているが，本実験では骨形成に 2 通りのパ ターンのあることが認められた。今回の標本採取は埋入 後 4 週からで, 組織形成域の広範な領域においてアパ夕 イト気孔壁に多核細胞が出現し, 特に多核細胞が密に配 列している領域で気孔壁に沿って骨芽細胞が分化し骨形 成がすでに生じている。この所見のみでは，骨形成が生 じている部の周囲に多核細胞が出現するという順も考え られるが，Ogiso らの行った大きさが $6 \times 6 \times 5 \mathrm{~mm}$ サイ ズの微細骨粉含浸多孔質アパタイトのより早期からの実 験では, 埋入後 2 週になるとブロック周辺の気孔壁に多 核細胞が出現し， 3 週で多核細胞が密に配列する領域の 一部で多核細胞が気孔壁から離脱し，骨芽細胞が気孔壁 面で分化し骨基質形成が始まると報告している ${ }^{26)}$ 。 4 週 以降，ブロック辺縁部では骨形成が生じており，その周 囲には常に多核細胞出現域がみられる。また Ogiso らは 微細骨粉を含浸させていない多孔質アパタイトの埋入実 験を行っており，微細骨粉を含浸させない場合にも気孔 壁に多核細胞が出現する領域で骨形成が生じていると報 告している ${ }^{26)}$ 。したがってマクロファージ系の細胞が気 孔壁にまず接触しそれが多核細胞になり，その後骨芽細 胞が分化するものと考えられる。この多核細胞にはアパ タイトの微細な一次粒子の取り込みがわずかにみられ， 多核細胞がアパタイトの気孔壁に作用する過程で骨芽細 胞の分化に必要ななんらかの因子が多核細胞から遊離 し，それが周囲の未分化な間葉系細胞から骨芽細胞への
分化を誘導しているものと推察される。

骨誘導を示す多孔質リン酸カルシウムセラミックスは いずれの報告のものもマクロ気孔壁に $1 \mu \mathrm{m}$ 以下〜数 $\mu \mathrm{m}$ のミクロ気孔を有する多孔質構造体である。 Havibovic らによる多孔質アパタイトは多孔質構造の グリーンボディの焼成温度を低くすることで粒成長およ び焼結を抑えアパタイト結晶相互間にミクロ気孔を残し た多孔体で ${ }^{23,29)}$ ，今回用いた多孔体は成型時の出発材料 としてアパタイト微結晶の凝集体である 15～20 $\mu \mathrm{m}$ 程 度の二次粒子仮焼体を使用することで $1,200^{\circ} \mathrm{C}$ の高温焼 成後も二次粒子相互間また二次粒子内にミクロ気孔を分 布させる方法である ${ }^{36)}$ 。骨誘導があるとする両多孔体に 共通する構造上の特徴は，マクロ気孔壁を構成するアパ タイト結晶相互間にミクロ気孔が分布することによりア パタイト結晶がマクロファージや多核細胞などに貪食さ れやすい構造となっていることである。これらのことか らも多核細胞のアパタイト気孔壁に対する作用が骨芽細 胞の分化に重要であることが窥える。また骨形成域の先 端では大きなマク口気孔に比べより小さなマクロ気孔内 で骨形成の始まる状態がみられること, $100 \mu \mathrm{m}$ 以上の 厚さのカプセリングが形成されている部では, 多核細胞 の出現域がブロック表面に近い部でも, 骨形成開始部位 は表面から $0.5 \mathrm{~mm}$ 程度内側であること，さらに貫通孔 周囲では多核細胞が貫通孔表面からブロック内に向かっ て連続して出現し, 形成されている骨は貫通孔壁内側か らみられ骨未形成域を残していないことから，多核細胞 から産生される因子がより多くしかも蓄積しやすい環境 が骨芽細胞の分化に有利であると推測される。

また多核細胞はブロック周辺のすべての部に出現する わけではない。ブロック周囲にカプセリングが薄い部で はブロック表面寄りに多核細胞の出現しない領域が比較 的広い。特になんらかの物理的外圧によりブロック表面 が崩壊している部では, 多核細胞の出現しない領域が広 く気孔内に骨粉の残存が多い。このことはマクロファー ジ系細胞から多核細胞が形成される過程においてもなん らかの因子の蓄積が必要で，その因子が放出されやすい 環境では多核細胞も出現しづらいものと思われる。ブ ロック表面崩壊部に出現する多核細胞は骨形成域でみら れる細胞より大きく細胞内へのアパタイトの取り込みが より明確であり，いわゆる異物性巨細胞と考えられるが, 骨形成域周囲にみられる多核細胞と同様の細胞であるか 否かは不明である。

以上のことからブロック内の骨形成をブロック表面か ら生じさせるためには，多核細胞または骨芽細胞に必要 な因子の気孔内からの放出を最小限にするとともに，毛 細血管の侵入が容易であるという両要素を備えた多孔質 構造体の検討が必要である。 
他の骨形成のパターンは 8 週, 16 週のブロック内側で みられる。埋入 8 週後のブロック内部の組織未形成域, また骨形成が生じていない組織形成域では，微細骨粉の 凝集域において個々の骨粉の石灰沈着が六進し，互いの 骨粉が融合するとともにその凝集塊の肥大化がみられ， さらに一部ではアパタイト気孔壁を構成する二次粒子に も石灰沈着がみられ始める。埋入後 8 週の骨形成域より 内側の $0.5 \mathrm{~mm}$ 程度の組織形成域の多くの部では, 気孔 壁や骨粉凝集塊への多核細胞の出現またそれらへの骨芽 細胞による骨前質の追加形成による通常の骨形成が進行 している。しかし一部では，多核細胞が特にみられない 状態で，石灰化した大きな骨粉凝集塊や気孔壁の周囲に 比較的密な線維からなる骨前質様組織が形成され，その 組織が気孔壁また骨粉凝集から石灰化していく状態や， 気孔壁や骨粉凝集塊の周囲にいまだ疎な線維が形成され ているにすぎないにもかかわらず，それらの線維に沿っ て石灰化域が拡大する状態がみられる。このようなパ ターンで骨が形成されている部の気孔内は石灰化組織で 満たされ髄腔形成がない。骨前質様組織には通常の骨前 質に近いものから太い線維側の集まりにすぎないものま でさまざまな状態がみられるが，その組織の表面および 内部には骨芽細胞様細胞がみられること，また骨形成域 から連続していることから, 通常の骨形成に近いとも解 釈される。しかし，いまだ柾な線維が形成されているに すぎない部で石灰化域が拡大している部にそのような細 胞はみられない。このような石灰化域もやがて骨前質様 組織に囲まれるが，16 週の貫通孔 $0 \mathrm{~mm}$ のブロック中央 部で骨形成域から完全に離れた領域においても同様の石 灰化が生じている。これらの所見からブロック内では骨 芽細胞の分化とは無関係に気孔壁や骨粉に石灰沈着が六 進し，その石灰化域が周囲の線維組織に拡大する可能性 がある。

Fujibayashi らは生体液はアパタイトに対して過飽和 な状態にあるため, アパタイトの核形成を誘起する化学 種が存在すると，その表面に骨類似アパタイトが析出す るとしている ${ }^{43)}$ 。また多孔質りン酸カルシウムセラミッ クスの骨誘導能の機序として, 溶解しやすい構造体から カルシウム, リン酸イオンの溶出がまず起こり,セラミッ クス表面に生体アパタイトの再沈着が生じ, その際, 内 因性の BMP の濃度が上昇し, やがて骨芽細胞が分化す

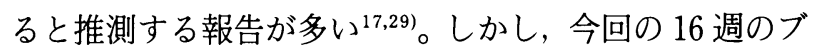
ロックに扔ける骨未形成域で気孔壁や骨粉凝集塊の石灰 沈着が亢進し，その結果 $100 \mu \mathrm{m}$ を超えるサイズの骨粉 凝集塊が散在しているにもかかわらず，気孔壁そのもの の構造は光学顕微鏡レベルでは基本的に変化がみられな い。前述のように体液のカルシウム濃度は過飽和状態に あり, 必ずしも気孔壁の石灰沈着が溶解した後の再沈着
とは限らない。また多くの多孔質アパタイトの骨誘導に 関する報告は，埋入後初期におけるブロック内の組織変 化に関する記載はみられない。大きなブロックの埋入後, 比較的長期に及び，しかもブロックのかなり内側に形成 されている骨は，骨芽細胞による骨形成と骨粉，気孔壁 の石灰化が一体となっている。いずれにしても本実験で, ブロックの内側ではアパタイト気孔壁が骨芽細胞とは無 関係に石灰沈着する事実は確認されたが，気孔壁の石灰 沈着と骨芽細胞の分化を関連づけられる所見は認められ なかった。

\section{4.ブロック周辺部の骨形成について}

骨形成機序に関する項でも記載したように，ブロック 表面側では多核細胞の出現また骨芽細胞の分化に要する 因子がブロック外に放出されやすく，特にカプセリング が薄くしかも外圧が加わりやすい部ではそれら因子の蓄 積が困難であると考えられる。多孔質構造体のマク口気 孔また連通孔を，今回用いたものより大きくした多孔質 構造体を使用した場合，この問題はさらに大きくなる危 険性が考えられる。

Havibovic らは小さなブロックよりも大きなブロッ クのほうが骨誘導能が高いとしている ${ }^{23)}$ 。彼らが骨誘導 能があるとする多孔質構造体のマクロ気孔の作製方法 は，著者らが用いている多孔体の泡を混入する方法では なく, 過酸化水素を混入したスラリーにナフタレン粒子 を混ぜ $80^{\circ} \mathrm{Cで}$ 加熱乾燥させ多孔質構造のグリーンボ ディを作製し，焼成している。その多孔体のマクロ気孔 のサイズは $50 \sim 1,000 \mu \mathrm{m}$ で, 平均 $400 \mu \mathrm{m}$ とし, 連通孔 については特に記載がない。マクロ気孔が今回の実験に 用いたものに比べかなり大きく，しかも一般に過酸化水 素を用いて発泡させると，泡を混入させた場合と異なり 大きな気孔が広範囲にわたり連続して形成されやすくな るため，著者らが用いた多孔体の $150 \mu \mathrm{m}$ のマクロ気孔 とわずか $40 \mu \mathrm{m}$ の連通孔が交互に連続するような構造 にはならない。つまり Havibovic らの報告は著者らが用 いている多孔体に比べ骨形成に必要なさまざまな因子が 非常に放出されやすい構造体を用いた結果の報告である といえる。このような構造であるため, 小さなブロック より大きなブロックのほうが骨誘導能が高く，またブ ロック内の骨形成はそのかなり内側から始まる結果に なったものと思われる。いずれにしても多孔質アパタイ トまたリン酸カルシウムの骨誘導能はその多孔質構造に 大きく影響される。

\section{V . 結 論}

マクロ，ミクロの連続気孔を有する多孔質アパタイト には異所性骨形成能があり，これに微細骨粉を含浸させ ることでその骨形成能は飛躍的に向上する。しかし，多 
孔質アパタイトブロックのサイズが大型化すると内部の 骨形成が困難になる。そこで今回, 直径 $10 \mathrm{~mm}$, 長さ 10 $\mathrm{mm}$ の大型円柱状多孔質アパタイトブロックを用い，そ れに直径 1，2，3 mm の栄養貫通孔を長軸方向にそれぞ れ 1 つ設けたものおよび設けないもの計 4 種の微細骨粉 含浸ブロックを成犬の皮下脂肪組織に $4,8,16$ 週間埋入 し, 各ブロック内に抢ける骨形成状態を検索し, 以下の 結論を得た。

1.ブロック内の骨形成は，その辺縁部のやや内側に おいてマクロ気孔壁に沿って多核細胞が密に出現する領 域の一部で，骨芽細胞が気孔壁に沿って出現することに その端を発する。

2 . 埋入後 4 週から 16 週にかけて, 気孔壁に沿った骨 および気孔内の骨髄様組織からなる骨形成域は徐々にブ ロック周囲でリング状に拡大するとともに内方また外側 に向かって拡大する。また貫通孔 $2 \mathrm{~mm}, 3 \mathrm{~mm}$ のブロッ クでは貫通孔に沿っても良好な骨形成が生じた。

3.8 週以降では, ブロック内側における骨形成域の 深部で石灰沈着が生じた気孔壁や石灰沈着により肥厚し た骨粉凝集塊周囲に比較的密な線維組織が形成され気孔 内全体が石灰化する状態や，骨粉凝集塊や気孔壁周囲の 疎な線維に石灰化域が拡大する状態も認められた。

4. 埋入後 16 週にいたると $3 \mathrm{~mm}$ の貫通孔をもつブ ロックではその中央レベルにおいても多孔質アパタイト 部分のほぼ全域が骨形成域となった。しかし他のブロッ クではブロック内に骨未形成域が残存し，特に貫通孔の ないブロックまた $1 \mathrm{~mm}$ の貫通孔のブロックでは中央 レベルにおいて骨未形成域が広範囲に残った。

以上のことから, 大型ブロックを用いて良好な骨形成 を得るためには栄養貫通孔の重要性が認められた。また 骨形成はブロック周囲に形成される密な線維からなる力 プセリングの厚さによって影響され, カプセリングの薄 い部ではブロック内の組織形成が早く進行するものの辺 縁部の骨形成が遅れ，特に外圧が加わった部で遅れるこ と, またカプセリングが $200 \mu \mathrm{m}$ 以上の厚さの部ではブ ロック表面側から内方への骨形成の拡大が遅れることも 認められた。

稿を終えるにあたり, 終始ご指導を賜りました本学大学院 医歯学総合研究科䂓顔面解剖学分野 山下靖雄教授に深く感 謝いたします。また本研究に関し多大なるご助言, ご教示を いただきました本教室非常勤講師 小木曽 誠博士に, 心から 感謝の意を表します。また, 終始ご協力を頂きました䫈顔面 解剖学分野の諸先生方に厚くお礼申し上げます。また, 多孔 質アパタイトを提供して頂いた, ペンタックス株式会社に厚 く抢礼申し上げます。
本論文の要旨の一部は, 19th European Conference on Biomaterials (2005 年 9 月 12 日, Sorrento, Naples, Italy) において発表した。

\section{文献}

1) Moy, P. K., Lundgren, S. and Holmes, R. E. : Maxillary sinus augumentation: Histomorphometric analysis of graft materials for maxillary sinus floor augumentation. J. Oral Maxillofac. Surg. 51:857-862, 1993.

2) Parikh, S. N. : Bone graft substitutes: Past, Present, Future. J. Post-grad. Med. 48:142-148, 2002.

3) Burchardt, H. : Biology of bone transplantation. Orth op. Clin. North Am. $18: 187-196,1987$.

4) Ogiso, M., Tabata, T., Ichijo, T. and Borgese, D. : Bone calcification on the hydroxyapatite dental implant and the bone-hydroxyapatite interface. J. Long-Term Effects Med. Implants 2:137-148, 1992.

5) Daculusi, G., Passuti, N., Martin, S. and Deudon, C. : Macroporous calcium phosphate ceramics for long bone surgery in humans and dogs; clinical and histological study. J. Biomed. Mater. Res. 24 : 379-396, 1990.

6) Ayers, R. A., Simske, S. J., Mumes, C. R. and Worldford, L. M. : Long-term bone ingrowth and residual microhardness of porous block hydroxyapatite implants in humans. J. Oral Maxillofac. Surg. 56 : 1297-1301, 1998

7) Jarcho, M. : Calcium phosphate ceramics as hard tissue prosthetics. Clin. Orthop. $157: 259-278,1981$.

8) Urist, M. R., DeLange, R. J. and Finerman, G. A. : Bone cell differentiation and growth factors. Science $220: 680-686,1983$

9) Cook, S. D. and Rueger, D. C. : Osteogenic protein-1. Clin. Orthop. 326:29-38, 1996.

10) Riley, E. H., Lane, J. M., Urist, M. R., Lyons, K. M. and Liberman, J. R. : Bone morphogenetic protein-2. Clin. Orthop. 324:39-46, 1996.

11) Goshima, J., Goldberg, V. M. and Caplan, A. I. : The osteogenic potential of culture-expanded rat marrow mesenchymal cell assayed in vivo in calcium phosphate ceramic blocks. Clin. Orthop. Relat. Res. 262 : 298-311, 1991.

12) Ohgushi, H., Dohi, Y. and Tamai, S.: Osteogenic differentiation of marrow stromal stem cell in porous hydroxyapatite ceramics. J. Biomed. Mater. Res. 27 : 1401-1407, 1993.

13) Ohgushi, H., Goldberg, V. M. and Caplan, A. I. : Heterotopic osteogenesis in porous ceramics induced by marrow cells. J. Orthop. Res. $7: 568-578,1989$.

14) Yuan, H., van den Doel, M., Li, S. H., van Blitterswijk, C. A., de Groot, K. and de Brujin, J. D. : A comparison of the osteoinductive potential of two calcium phosphate ceramics implanted intramuscularly in goats. J. Mater. Sci. Mater. Med. 13 : 1271-1275, 2002.

15) Yamasaki, H. and Sakai, H. : Osteogenic response to porous hydroxyapatite ceramics under the skin of dogs. Biomaterials $13: 308-312,1992$.

16) Ripamonti, U.: Osteoinduction in porous hydroxyapatite implanted in heterotopic sites of different animal models. Biomaterials $17: 31-35,1996$.

17) Ripamonti, U. and Crooks, J. : Sintered porous 
hydroxyapatites with intrinsic osteoinductive activity: geometric induction of bone formation. South Afr. J. Sci. $95: 335-343,1999$.

18) Klein, C., de Groot, K., Chen, W., Li, Y. and Zhang, $\mathrm{X}$. : Osseous substance formation induced in porous calcium phosphate ceramics in soft tissues. Biomaterials $15: 31-34,1994$.

19) Yang, Z., Yuan, H., Tong, W., Zou, P., Chen, W. and Zhang, X. : Osteogenesis in extraskeletally implanted porous calcium phosphate ceramics: variability among different kinds of animals. Biomaterials 17 : 31-37, 1996.

20) Yuan, H., Yang, Z., Li, Y., Zhang, X., de Bruijn, J. D. and de Groot, K. : Osteoinduction by calcium phosphate biomaterials. J. Mater. Sci. Mater. Med. 9 : 723726, 1998.

21) Yuan, H., Kurashina, K., de Bruijn, J. D., Li, Y., de Groot, K. and Zhang, X. : A preliminary study on osteoinduction of two kinds of calcium phosphate ceramics. Biomaterials $20: 1799-1806,1999$.

22) Kurashina, K., Kurita, H., Wu, Q., Ohtsuka, A. and Kobasashi, H.: Ectopic osteogenesis with biphasic ceramics of hydroxyapatite and tricalcium phosphate in rabbits. Biomaterials 23:407-412, 2002.

23) Habibovic, P., Sees, T. M., Mirella, A., Clemens, A., van Blitterswijk, C. A. and de Groot, K. : Osteoinduction by biomaterials physicochemical and structural influences. J. Biomed. Mater. Res. 77 A : 747-762, 2006.

24) Gosain, A. K., Song, L., Riordan, P., Amarante, M. T., Nagy, P. G., Wilson, C. R., Toth, J. M. and Ricci, L. A. : 1-year study of osteoinduction in hydroxyapatite-derived biomaterials in an adult sheep model : Part 1. Plast Reconstr. Surg. 109:619-630, 2002.

25) Le Nihouannen, D., Daculsi, G., Saffarzadeh, A., Gautheir, O., Delplace, S., Pleit, P. and Layrolle, P. : Ectopic bone formation by microporous calcium phosphate ceramic particles in sheep muscles. Bone 36 : 1086-1093, 2005.

26) Ogiso, M., Mineno, S. and Matumoto, T. : Bone regeneration using fine bone powder and porous hydroxyapatite. The Journal of Japanease Orthopaedic Surgical Society $78: 799,2004$.

27) Takemoto, M., Fujibayashi, S., Neo, M., Suzuki, J., Matsushita, T. and Kokubo, T.: Osteoinductive porous titanium implants : effect of sodium removal by dilute $\mathrm{HCl}$ treatment. Biomaterials 26 : 2682-2691, 2006.

28) Kryut, M. C., de Bruijn, J. D., Wilson, C. E., Yuan, H., van Blitterswijk, C. A., Verbout, A. J., Oner, F. C. and Dhert, W. J. A. : Optimization of bone tissue engineering in goats: a preoperative seeding method using cryopreserved cells and localized bone formation in calcium phosphate scaffolds. Transplantation 77 : 359-365, 2004
29) Habibovic, P., Li, J., van der Valk, C. M., Meijer, G., van Blitterswijk, C. A. and de Groot, K.:3 D microenvironment as essential element for osteoinduction by biomaterials. Biomaterials $26: 3565-3575$, 2005.

30）小木兽 誠：微細骨粉を含浸させた生体適合性材料から なる構造体抢よびその製造方法。特許 3820396

31）クラース・デ・グルート：骨誘発生体適合材料。特開 2000-93504.

32) Damien, C. J. and Parsons, J. R. : Bone graft and graft substitutes : a review of current technology and applications. J. Appl. Biomater. 2 : 187-208, 1991.

33) Hollingerm, J. O., Brekke, J., Gruskin, E. and Lee, D. : Role of bone substitutes. Clin. Orthop. 324:55-65, 1996.

34) Jarcho, M. : Calcium phosphate ceramics as hard tissue prosthetics. Clin. Orthop. 157 : 259-278, 1981.

35) Urist, M. R. : Bone formarion by autoinduction. Science 150:893-899, 1965.

36) Sakamoto, M., Matsumoto T., Nakasu, M., Ogawa, T. and Okihama, H. : Development and evaluation of porous hydroxyapatite ceramics with high porosity. Eur. Conf. Biomater. 19: 43, 2005.

37) Tanaka, H., Wakisaka, A., Ogasa, H., Kawai, S. and Liang, C. T. : Effects of basic fibroblast growth factor on osteoblast-related gene expression in the process of medullary bone formation induced in rat femur. $\mathrm{J}$. Bone Miner. Metab. 21 (2) : 74-79, 2003.

38) Kaito, T., Myoui, A., Takaoka, K., Saito, N., Nishikawa, M., Tamai, N., Ohgushi, H. and Yoshikawa, H. : Potentiation of the activity of bone morphogenetic protein-2 in bone regeneration by a PLA-PEG/ hydroxyapatite composite. Biomaterials $26: 73-79$, 2005.

39) Allan, E. H., Ho, P. W., Umezawa, A., Hata, J., Makishima, F., Gillespie, M. T. and Martin, T. J. : Differentiation potential of a mouse bone marrow stromal cell line. J. Cell Biochem. 90 : 158-169, 2003.

40) Nishikawa, M., Myoui, A., Ohgushi, H., Ikeuchi, M., Tamai, N. and Yoshikawa, H. : Bone tissue engineering using novel interconnected porous hydroxyapatite ceramics combined with marrow mesenchymal cells : quantitative and three-dimensional image analysis. Cell Transplant. 13:367-376, 2004.

41) Terada, N., Hamazaki, T., Oka, M., Hoki, M., Mastalerz, D. M., Nakano, Y., Meyer, E. M., Morel, L., Petersen, B. E. and Scott, E. W. : Bone marrow cells adopt the phenotype of other cells by spontaneous cell fusion. Nature 416:542-545, 2002.

42) Ying, Q. L., Nichols, J., Evans, E. P. and Smith, A. G. : Changing potency by spontaneous fusion. Nature 416:545-548, 2002.

43) Fujibayashi, S., Neo, M., Kim, H-M., Kokubo, T. and Nakamura, T. : Osteoinduction of porous bioactive titanium metal. Biomaterials 25 : 443-450, 2004. 